\title{
An Empirical Study on Factors Responsible for Bullwhip Effect in Soya Oil Manufacturing Sector
}

\author{
Dr. Shweta Mogre ${ }^{1}$, Dr. V.K. Jain ${ }^{2}$, Dr. P.K. Jain ${ }^{3}$ \\ ${ }^{1}$ Associate Professor, Pioneer Institute of Professional Studies, Indore, India \\ ${ }^{2}$ Professor and Dean, Mody University of Science and Technology, Lakshmangarh, India \\ ${ }^{3}$ Professor and Principal, Pioneer Institute of Professional Studies, Indore, India
}

\begin{abstract}
Order variability increases as the orders move upstream in the supply chain. This phenomenon is known as the bullwhip effect. There are several causes due to which this effect occurs. In this paper, we tried to identify the causes which are responsible for Bullwhip Effect in Soya Oil Manufacturing Sector of Indore region and suggested some strategies for reducing the Bullwhip Effect.
\end{abstract}

Key Words: Bullwhip Effect, Order variability, Supply Chain

\section{Introduction}

Today most of manufacturing industries are passing through a phase of very tough competition due to globalization, product variety and technological breakthroughs. In Present scenario, customers desire better quality, design, innovation, choice, convenience and service on a cheaper price and effort. In such a situation making optimal decision under uncertain conditions is a challenging job for industries. In industries, the supply chain consists of so many layers but managers make decisions on the basis of localized information and decisions are hidden from other members of the chain. This creates information distortion; the gap between the forecast and reality is large and leads to product shortfalls or inventory excess. This variation in demanddelivery cycle is called Bullwhip Effect, which is a very important phenomenon in supply chain. As one moves up in a supply chain i.e. away from the consumer demand, the volatility in demand increases. Customer demand is rarely stable, manufacturer must forecast demand to fulfill the requirement of customers. But, forecast may or may not be true and error arises. This effect is also known as whiplash or whipsaw effect and it can be reduced if actual demand of customer goes to supplier. Then the supplier can adjust their production schedule and as a result; inventory reduced significantly. The bullwhip phenomenon was first described by Forrestor [16] in 1958, after that in 1980's, it is identified through simulation approach. It is well-researched topic in the area of Supply Chain Management. Now a day's large amount of literature is available on bullwhip effect and its impact on the supply chain performance can be measured in various industrial sectors.

\section{Bullwhip Effect}

The Bullwhip Effect on the supply chain occurs when changes in consumer demand causes the companies in a supply chain to order more goods to meet the new demand. The bullwhip effect usually flows up the supply chain, starting from the retailer, wholesaler, distributor, manufacturer and then the raw materials supplier. This effect can be observed through most supply chains across several industries; it occurs because the demand for goods is based on demand forecasts from companies, rather than actual consumer demand. The Bullwhip is an observed phenomenon of various industries. Small changes in consumer demand can result in large variations in orders placed upstream. The first recorded documentation of this phenomenon is probably due to Forrester [16], (1958) in industrial dynamics, he called it "Demand Amplification". Historically, the Bullwhip Effect had been accepted as a normal occurrence of the order-to-delivery cycle. It is observed that the order pattern in upstream direction is highly variable than downstream. The amplification in order variation may cause irrational decision-making [13]. Figure indicates the variation in demand between different stages of supply chain.

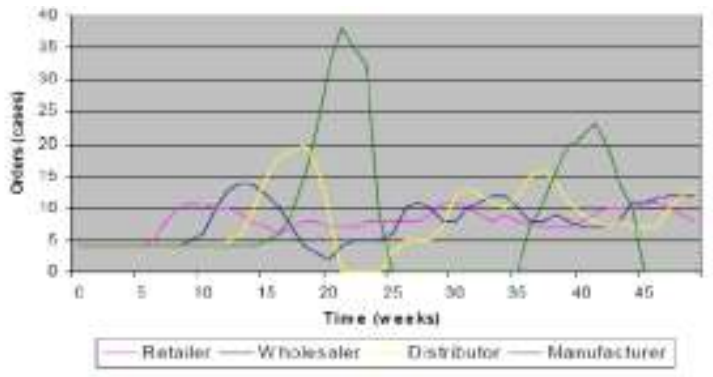

Figure 1. Variation in order pattern in Bullwhip Effect [14] 
The bullwhip is characterized by oscillations of orders at each level of the supply chain and an amplification of these oscillations farther up the problem [15]. The real meaning of the bullwhip effect is that orders to suppliers tend to chain away from the marketplace [12]. The Beer Game developed at MIT is very popular in many business schools and executive seminars and is very useful for illustrating the bullwhip have larger variance than sales to the buyer. This topic becomes more complex when there are more chains in the supply chain. This distortion of demand is amplified when demand is passed upstream. Lee et al., (1997) [13] first exposed the term "Bullwhip" when they visited Procter and Gamble in the early 1990's. After that they realized the occurrence of bullwhip effect in so many industries and found that it is unavoidable.

\section{Soya Oil Manufacturing Organizations In Indore}

India is a vast country and residents of numerous of its states have developed a specific liking for certain oils and they also mostly depending upon the oils available in that particular region. Madhya Pradesh is a one of the leading producer of edible oils. more specifically Soyabean Oil. Today, Madhya Pradesh has a unique identity as the soya producing state of India. It produces $54 \%$ of the total production of soya in the country. The western and north-western parts of Madhya Pradesh are major soya producing areas. Prominent investors in Madhya Pradesh's edible oil industry are Ruchi Soya, MP Glychem and Vippi Industries at Indore. Ruchi Soya is expanding the capacity of its edible oil refinery at Indore from 600 tonnes per day to 1,000 tonnes per day. Prosoya Foods, a subsidiary of ProSoya Inc. Canada has set up a soya milk extraction plant in Madhya Pradesh. [17] [Source: INDIAN STATES Economy and Business Madhya Pradesh]

\section{Objectives}

The main objectives of this research are:

$>$ To explore major causes responsible for Bullwhip Effect.

$>$ To suggest the strategies reduce the Bullwhip Effect

\section{About The Area Of Research Study}

Indore is located in the western region of MP. Major industrial areas surrounding the city include the Pithampur Special Economic Zone (SEZ) and the Sanwer Industrial belt. The SEZ of Indore has spread over 1,038 hectares of land. The SEZ has attracted investment of over US\$ 200 million so far. The industries located in the SEZ include Textile, Pharmaceuticals, Automobile \& Auto Ancillary, Metallurgy and Leather [17] .For the purpose of this research study, Soya Oil Manufacturing Companies namely Ruchi Soya Industries Limited and Kriti Nutrients Limited nearby Indore city were selected.

\section{Research Design And Methodology}

For this study, the data was collected from two soya oil manufacturing units. The primary data was collected from the executives of Sales, Marketing, and Production Heads of these units. Four executives were taken from each unit. Thus, total sample size was 8. Sampling is statistical method of obtaining representative data or observations from a group. For the purpose of this study, Non Probability Convenience Sampling was used. Self Designed Questionnaire was used for collecting Primary data for finding the factors responsible for bullwhip effect. To find out various parameters, content validity was carried out by reviewing various research papers. Factor Analysis was applied by SPSS with varmax rotation and Kaiser normalization to find out the factor responsible for Bullwhip Effect.

\section{Data Analysis, Interpretation And Results}

To find out the foremost causes, which are responsible for Bullwhip Effect Questionnaire consisting of 23 statements related to causes responsible for Bullwhip Effect was executed. The results obtained from the collected data are as follows:

Table 1. Showing the response on Bullwhip Parameters

\begin{tabular}{|c|c|c|c|c|c|c|c|c|}
\hline \multirow[b]{2}{*}{ S.N } & \multirow[t]{2}{*}{ Causes } & \multicolumn{5}{|c|}{ Percentage of Respondents } & \multirow[t]{2}{*}{ Total (500) } & \multirow[b]{2}{*}{ Rank } \\
\hline & & $\begin{array}{l}\text { Highly } \\
\text { Respo } \\
\text { nsible } \\
(5) \\
\end{array}$ & $\begin{array}{l}\text { Resp } \\
\text { onsib } \\
\text { le (4) }\end{array}$ & Can't say (3) & $\begin{array}{l}\text { Least } \\
\text { Respo } \\
\text { nsible } \\
(2) \\
\end{array}$ & $\begin{array}{l}\text { Not } \\
\text { Respon } \\
\text { sible } \\
\text { (1) } \\
\end{array}$ & & \\
\hline 1 & Price of Materials & 25 & 75 & 0 & 0 & 0 & 425 & 5 \\
\hline 2 & Financial stability of suppliers & 25 & 12.5 & 37.5 & 25 & 0 & 337.5 & 9 \\
\hline 3 & Material lead times too long & 25 & 75 & 0 & 0 & 0 & 425 & 5 \\
\hline 4 & Trust between you and your suppliers & 25 & 75 & 0 & 0 & 0 & 425 & 5 \\
\hline 5 & Cost of replacing outdated technology & 12.5 & 25 & 50 & 12.5 & 0 & 337.5 & 9 \\
\hline 6 & Capacity limitations due to capital funding & 25 & 75 & 0 & 0 & 0 & 425 & 5 \\
\hline 7 & $\begin{array}{l}\text { Output based on customer's forecast to } \\
\text { plan }\end{array}$ & 12.5 & 75 & 12.5 & 0 & 0 & 400 & 7 \\
\hline 8 & Labour problems - availability of skills & 62.5 & 37.5 & 0 & 0 & 0 & 462.5 & 2 \\
\hline 9 & Labour problems - time-consuming to & 25 & 50 & 25 & 0 & 0 & 400 & 7 \\
\hline
\end{tabular}


An Empirical Study on Factors responsible for Bullwhip Effect in Soya Oil Manufacturing Sector

\begin{tabular}{|c|c|c|c|c|c|c|c|c|}
\hline & resolve & & & & & & & \\
\hline 10 & $\begin{array}{l}\text { Capacity limitations due to customer order } \\
\text { fluctuation }\end{array}$ & 25 & 62.5 & 12.5 & 0 & 0 & 412.5 & 6 \\
\hline 11 & Reducing cycle time & 25 & 75 & 0 & 0 & 0 & 425 & 5 \\
\hline 12 & Balancing inventory levels & 25 & 12.5 & 37.5 & 25 & 0 & 337.5 & 9 \\
\hline 13 & Integrating information systems internally & 37.5 & 37.5 & 25 & 0 & 0 & 412.5 & 6 \\
\hline 14 & $\begin{array}{l}\text { Capacity limitations due to availability of } \\
\text { skilled labour }\end{array}$ & 12.5 & 75 & 12.5 & 0 & 0 & 400 & 7 \\
\hline 15 & $\begin{array}{l}\text { Integrating technology with suppliers and } \\
\text { customers }\end{array}$ & 50 & 50 & 0 & 0 & 0 & 450 & 3 \\
\hline 16 & Cancellation of orders & 37.5 & 62.5 & 0 & 0 & 0 & 437.5 & 4 \\
\hline 17 & $\begin{array}{l}\text { Excessive and slow-moving inventory due } \\
\text { to cancellation of orders }\end{array}$ & 75 & 25 & 0 & 0 & 0 & 475 & 1 \\
\hline 18 & $\begin{array}{l}\text { Rapid changes in demand (in terms of } \\
\text { quantity patterns) }\end{array}$ & 37.5 & 62.5 & 0 & 0 & 0 & 437.5 & 4 \\
\hline 19 & $\begin{array}{l}\text { Advance communication about market } \\
\text { demand }\end{array}$ & 25 & 25 & 25 & 25 & 0 & 350 & 8 \\
\hline 20 & $\begin{array}{l}\text { Too dependent on business of a particular } \\
\text { customer }\end{array}$ & 37.5 & 62.5 & 0 & 0 & 0 & 437.5 & 4 \\
\hline 21 & Trust between you and your customers & 25 & 62.5 & 12.5 & 0 & 0 & 412.5 & 6 \\
\hline 22 & Relationship with customers & 25 & 75 & 0 & 0 & 0 & 425 & 5 \\
\hline 23 & $\begin{array}{l}\text { Little or no assistance from customers in } \\
\text { complying with their requirement }\end{array}$ & 25 & 12.5 & 37.5 & 25 & 0 & 337.5 & 9 \\
\hline
\end{tabular}

Percentage analysis of collected responses indicates that all the causes are little or more responsible for Bullwhip Effect. Financial stability of suppliers, cost of replacing outdated technology, balancing inventory levels, little or no assistance from customers in complying with their requirements and advance communication about market demand are the causes for which respondents were not sure or having dilemma that these causes are responsible for bullwhip effect or not? Where as most responsible causes for presence of Bullwhip Effect are Excessive and slow-moving inventory due to cancellation of orders (Rank 1), availability of skilled labour (Rank 2) and Integrating technology with suppliers and customers (Rank 3).3

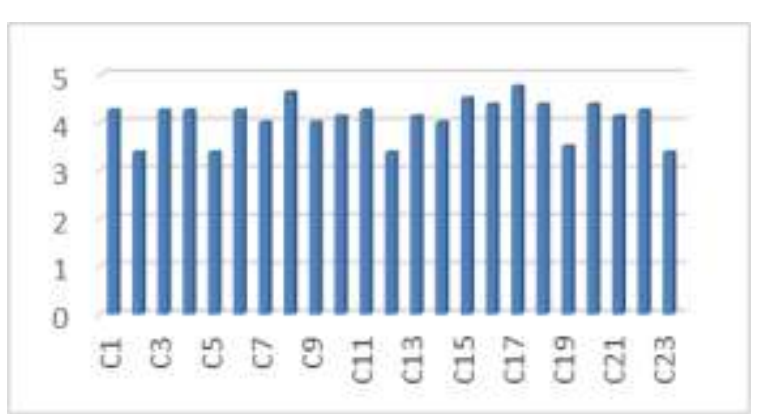

Figure 2. Causes Responsible for Bullwhip Effect

As per the study, the most responsible causes for Bullwhip Effect are availability of skilled labour and excessive and slow-moving inventory due to cancellation of orders. Whereas financial stability of suppliers cost of replacing outdated technology, balancing inventory levels, little or no assistance from customers in complying with their requirements andadvance communication about market demand are the least responsible causes for Bullwhip effect in Soya oil manufacturing companies nearby in Indore City.

\section{Factor Analysis}

To find out the foremost causes, which are responsible for Bullwhip Effect, the Factor Analysis of SPSS 21.0 was performed on the Questionnaire consisting of 23 statements related to causes responsible for Bullwhip Effect. There were 5 factors identified which are responsible for Bullwhip Effect. Nomenclature of these factors was done on the basis of similarity and common characteristics. These factors with their Cumulative percentage Loadings are as follows:

Table 2.Factor Analysis Table

\begin{tabular}{|l|l|l|l|l|}
\hline Factor & ITEM & ITEM LOAD & $\begin{array}{l}\text { FACTOR } \\
\text { LOAD }\end{array}$ & $\begin{array}{l}\text { PERCENTAGE } \\
\text { VARIANCE }\end{array}$ \\
\hline Lead Time & & & 4.023 \\
Variability, Capacity & Relationship with customers & .956 & 45.954 \\
\cline { 2 - 3 } Limitation and & Material lead times too long & .956 & \\
Dependency on & Reducing cycle time & .956 & \\
\cline { 2 - 3 } & Trust between you and your customers & .927 & \\
\hline
\end{tabular}




\begin{tabular}{|c|c|c|c|c|}
\hline \multirow[t]{6}{*}{ Customers } & $\begin{array}{l}\text { Capacity limitations due to customer order } \\
\text { fluctuation }\end{array}$ & .854 & & \\
\hline & $\begin{array}{l}\text { Little or no assistance from customers in } \\
\text { complying with their requirements }\end{array}$ & .770 & & \\
\hline & Cost of replacing outdated technology & .760 & & \\
\hline & Balancing inventory levels & .704 & & \\
\hline & $\begin{array}{l}\text { Capacity limitations due to availability of } \\
\text { skilled labour }\end{array}$ & .577 & & \\
\hline & $\begin{array}{l}\text { Too dependent on business of a particular } \\
\text { customer }\end{array}$ & .563 & & \\
\hline \multirow{5}{*}{$\begin{array}{lr}\text { Price \& Demand } \\
\text { Fluctuation } \\
\text { Supplier Trust }\end{array}$} & Price of Materials & .959 & \multirow[t]{5}{*}{3.711} & \multirow[t]{5}{*}{20.084} \\
\hline & Trust between you and your suppliers & .959 & & \\
\hline & $\begin{array}{l}\text { Rapid changes in demand (in terms of } \\
\text { quantity patterns) }\end{array}$ & .830 & & \\
\hline & Cancellation of orders & .830 & & \\
\hline & Integrating information systems internally & .134 & & \\
\hline \multirow{4}{*}{$\begin{array}{l}\text { Technology } \\
\text { Integration \& \& } \\
\text { Financial Stability of } \\
\text { Supplier }\end{array}$} & Financial stability of suppliers & .954 & \multirow[t]{4}{*}{3.233} & \multirow[t]{4}{*}{16.451} \\
\hline & $\begin{array}{l}\text { Labour problems }- \text { time-consuming to } \\
\text { resolve }\end{array}$ & .864 & & \\
\hline & $\begin{array}{l}\text { Advance communication about market } \\
\text { demand }\end{array}$ & .734 & & \\
\hline & $\begin{array}{l}\text { Integrating technology with suppliers and } \\
\text { customers }\end{array}$ & .681 & & \\
\hline \multirow{2}{*}{$\begin{array}{l}\text { Cancellation of order } \\
\& \text { Availability of } \\
\text { Skilled Labour }\end{array}$} & Labour problems - availability of skills & .786 & \multirow[t]{2}{*}{.944} & \multirow[t]{2}{*}{9.605} \\
\hline & $\begin{array}{l}\text { Excessive and slow-moving inventory due to } \\
\text { cancellation of orders }\end{array}$ & .158 & & \\
\hline \multirow{2}{*}{$\begin{array}{l}\text { Forecast Error \& } \\
\text { Funding Limitation }\end{array}$} & Capacity limitations due to capital funding & .742 & \multirow[t]{2}{*}{1.398} & \multirow[t]{2}{*}{4.962} \\
\hline & Output based on customer's forecast to plan & .656 & & \\
\hline
\end{tabular}

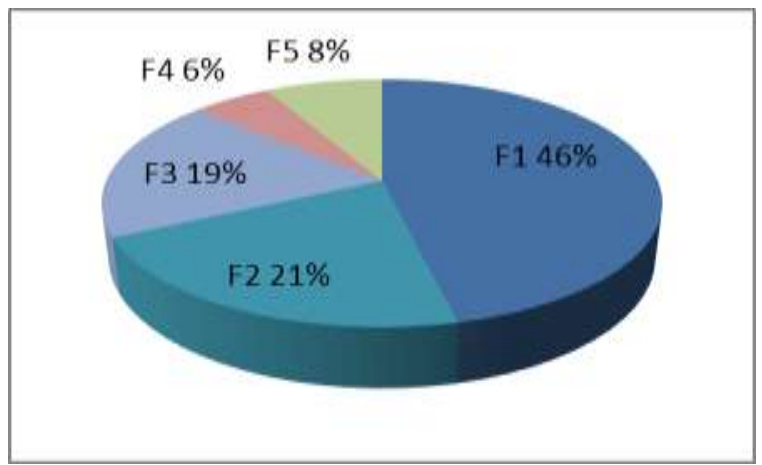

Figure 3. Percentage Analysis of Factors

Cleary Figure 3 indicates that Factor 1 namely Lead Time Variability, Capacity Limitation and Dependency on Customers is maximum responsible factor $(46 \%)$ for presence of Bullwhip Effect, Factor 2 i.e. Price \& Demand Fluctuation and Supplier Trust account for $21 \%$ for presence of Bullwhip Effect. Factor 3 namely Technology Integration \& Financial Stability of Supplier is $19 \%$ responsible whereas the Factor 4 Cancellation of order \& Availability of Skilled Labour and Factor 5 Forecast Error \& Funding Limitation are the least responsible factors( $6 \%$ and $8 \%$ respectively) for presence of Bullwhip Effect in Soya Oil Manufacturing Organizations of nearby Indore city.

\section{Strategies To Reduce Bullwhip Effect}

Following strategies have been suggested after reviewing various articles[1,2,5,6,7] talking to the respondents and advice taken from various experts that may help the Soya Oil Manufacturing Sector Companies for reducing the Bullwhip Effect and increase their company's performance: In this research, one of the most important factor which affects the bullwhip effect is Price Fluctuation. By maintaining consistent price, company can prevent buying surges triggered by temporary promotional discounts. There is an immediate impact of price fluctuations on the customer purchases. When prices are lowered due to market conditions, customers order more. Maintaining a consistent price even during market fluctuations decreases the bullwhip effect. Better understanding of the customers' demand can be achieved by improving communication in complete supply chain, which improves the correct forecast. This can help to minimize the bullwhip effect. Lack of demand visibility can be addressed by providing all key players in the supply chain with access to point of sale (POS) data. Suppliers and customers may collaborate to improve the quality and frequency of communication throughout the supply chain. They also can share information through an arrangement such as Vendor-Managed Inventory (VMI).Companies can improve operational efficiency to reduce highly variable 
demand and long resupply lead times. Companies can use electronic data interchange to reduce the cost of placing orders and place orders more frequently. By reducing lead times, company can decreases the Bullwhip Effect.

\section{Conclusion}

The economy of every country is supported by growth of its manufacturing industries. Currently, the manufacturing industries are passing through a phase of very tough competition. In order to survive, every industry has to strive to improve productivity in all spheres of activity. In this context, it is necessary to each and every manufacturing industry to improve its performance. Hence it is necessary to each manufacturing sector to identify the factors which are directly or indirectly having the impact on performance of manufacturing organization. The present study shows that there are several causes are responsible for Bullwhip Effect in the selected manufacturing companies of Indore region. These causes furthermore be factorized into five major factors. These factors are Lead Time Variability, Capacity Limitation and Dependency on Customers; Price \& Demand Fluctuation and Supplier Trust; Technology Integration \& Financial Stability of Supplier; Cancellation of order \& Availability of Skilled Labour; Forecast Error \& Funding Limitation. Out of these five factors Lead Time Variability, Capacity Limitation and Dependency on Customers are most responsible causes for occurrence of Bullwhip effect. Hence Companies can improve their operational efficiency by reducing highly variable demand and long resupply lead times.

\section{References}

[1]. Shweta Mogre, Dr. V.K. Jain, Dr. P.K. Jain (2015), An Empirical Study on Causes Responsible for Bullwhip Effect in Pharmaceutical Manufacturing Sector, SHODH-Pioneer Journal of IT and Management, Volume 11(2), ISSN no. 0974-8954 pp 216-220

[2]. Ravinder Kumar, Singh Rajesh K., Ravi Shankar (2015), Critical Success Factors for Implementation of Supply Chain Management in Indian Small and Medium enterprises and their Impact on Performance, IIMB Management Review 27, pp 92-104

[3]. Jun Shan, Shitao Yang, Shilei Yang and Jin Zhang (2014),An Empirical Study of the Bullwhip Effect in China, Production and Operations Management,Vol. 23, No. 4,pp. 537-551

[4]. Torres Octavio Carranza and Arnold B. Maltz (2010), Understanding The Financial Consequences of the Bullwhip Effect in A Multi-Echelon Supply Chain,Journal Of Business Logistics, Vol. 31, No. 1, Issue 1,pp 23-41

[5]. Padma Joshi, Dr. V.K.Jain, (2007), The Bullwhip Effect: A Review of Available Literature. Published in, "The new paradigms in supply chain management", Mahakal Institute of Management, Ujjain (M.P.).

[6]. Padma Joshi, Dr. Ashutosh Pathak, Dr. V.K.Jain, (2007), The Bullwhip Effect: A Conceptual Framework. Published in, “The Supply Chain Management in Global Environment,"Mahakal Institute of Management, Ujjain (M.P.)

[7]. Ravichandran, N., (2006), Managing Bullwhip Effect: Two Case Studies, Indian Institution of Management, Ahmedabad, W.P. No. 2006-08-01, August 2006.

[8]. Geary, S., Disney, S.M., Towill, D.R., (2006), On Bullwhip in Supply Chains-Historical Review, Present Practice and Expected Future Impact. International Journal of Production Economics, Volume 101, pp. 2-18.

[9]. Disney, S.M. and Towill D.R., (2006), A Methodology for Benchmarking Replenishment-Induced Bullwhip. Supply Chain Management: An International Journal, Volume 11, Number 2, pp. 160-168.

[10]. Wilck, J.H., (2006), Managing the Bullwhip Effect, (accessed from, http://www.engr.psu.edu / symposium 2006/session- 3D modeling and engineering applications/).

[11]. Croson Rachel and Donohue Karen (2006), Behavioral Causes of The Bullwhip Effect and The Observed Value of Inventory Information, Management Science, Vol. 52 Issue 3, pp323-336

[12]. Croson, R., Donohue, K., (2003), The Impact of POS Data Sharing on Supply Chain Management: An Experimental Study. Production and Operations Management, Volume 12, Pp.1-12.

[13]. Lee, H.L., Padmanabhan, V., Whang, S., (1997), The Bullwhip Effect in Supply Chains. Sloan Management Review, Volume 38, Number 3, Pp. 93-102.

[14]. Ackere, V., Larsen, A., Erik Reimer - Morecroft, John, D.W., (1993), Systems Thinking and Business Process Redesign: An Application to the Beer Game. European Management Journal, Volume 11, Number 4, pp. 412-423.

[15]. Sterman, J., (1989), Modelling Managerial Behaviour; Misperceptions of Feedback in A Dynamic Decision-Making Experiment. Management Science, Volume 35, Number 3, Pp. 321-339.

[16]. Forrester, J., (1958), Industrial dynamics: A Major Break Through for Decision-Makers. Harvard Business Review, Volume 36, Number 4, pp. 37-66._http://www.ibef.org/download/Madhya_Pradesh.pdf 